\title{
Response of finishing broiler chickens fed three energy/protein combinations at Fixed E:P ratio
}

\author{
O.M.O. Idowu ${ }^{1}$, Daisy Eruvbetine', O.O. Oduguwa', A.M. Bamgbose ${ }^{1}$ and S.S. Abiola ${ }^{2}$ \\ 'Department of Animal Nutrition, \\ ${ }^{2}$ Department of Animal Production and Health, University of Agriculture, P.M.B 2240, Abeokuta,
Nigeria.
}

\begin{abstract}
A feeding experiment was conducted to imestigate the response of finishing broiler chicken to diets containing three metabolizable energy (ME)/crude protein (CP) combinations (3203.76 ME vs $19.90 \% \mathrm{CP}, 2884.15 \mathrm{ME}$ vs $18.10 \% \mathrm{CP}$ and $2566.42 \mathrm{ME} \mathrm{vs} 18.10 \% \mathrm{CP}$ ) at fixed $\mathrm{ME}$. $\mathrm{CP}$ ratio of 160:1. A totat of 126 four weeks old broiler chickens were randomly allotted to three dietary treatments replicated thrice. The final live weight, weight gain, feed intake, feed conversion and PER significant ( $P<0.05)$ differences amod the control diet $(3203.76 \mathrm{ME}$ vs $19.90 \% \mathrm{CP})$. There were energy intake, CP: Gain and percentage morlality were statistically the same $(P=0.05)$ across the treatments. Cost per $k$ a feed decreased as the energy and the protein density of the diets decreased while the cost per $k g$ weight decreasing $(P<0.05)$ trend while nitrogen retention increased with decrease in energy-protein density of the diets. Values for the haematological parameters and blond chemistry were significantly $(P<0.01)$ higher in birds fed control diet and the values decreased with decreased levels broiler finisher diet are reduced at fixed L:P ratio the feed intake would increase while the feed utilization afficiency decreases
\end{abstract}

Keywords: Finishing broiler chickens, energy/protein combination, encrgy:protein ratio

\section{Introduction}

Scientists in Nigeria and abroad have worked on the encrgy and protein requirements of broiler chicken. Agricultural Research Council (ARC, 1975) and National Research Council (NRC, 1994) suggested that $3200 \mathrm{KCal} \mathrm{ME}$ per $\mathrm{kg}$ was adcquate in the finishing broiler ration. In the tropics, Olomu (1980) estimated energy requirement of finishing broiler chicken to be $3000 \mathrm{kCal} \mathrm{ME}$ per $\mathrm{kg}$ of feed. Babatunde and Fetuga (1976) in their studies on protein requirement of broiler recommended $\mathrm{CP}$ level of not less than $18 \%$ for finishing broiler chicken.
In another study, Olomu and Offiong (1980) recommended $20 \% \mathrm{CP}$ for finishing broiler. Fetuga (1984) in his study suggested CP of $19-$ $21 \%$ for $5-9$ weeks old broiler chickens while NRC (1994) recommended a little lower CP of $18-20 \%$ for finishing broiler. However, the importance of energy/protein concentration ratio in the diet of poultry particularly broiler chickens has been stressed by many workers (Boorman and Wilson, 1977; Scott et al., 1982; Bondi. 1987 and Pond et al., 1995). The common conclusion of the above researchers indicated that when the protein level of a diet is 
decreased there is always a concomitant widening of energy/protein ratio which increased feed intake in order to overcome a protein deficiency stress, and as a result of the over consumption of energy the feed efficiency of the diet was reduced since a considerable amount of energy is required for the synthesis of uric acid.

Presently there is dearth of information on the response of broiler chickens fed diets with varying protein and encrgy levels while cnergy/protein ratio is kept constant. This study. is therefore aimed at investigating the performance, nutrient utilization and $\cos / /$ benefit of feeding finishing broiler chickens different combination of protein/cnergy density at fixed E:P ratio.

\section{Materials and Methods}

\section{Experimental Birds and Design}

A total of 126 unsexed four weeks old broiler chickens of commercial broiler strain (Ariak $2000)$ were randomly allotted to eightecn replicate groups of seven chickens each. Six groups were assigned to each of the three dietary treatments. The experiment was arranged in a completely randomized design with dietary protein as the only source of variation. To achieve this all rations were formulated to have approximately the same energy/protein ration. To minimize any amino acid imbalances, the proportion of maize/soybean ratio was kept constant at 1:22:1 by making up the decreasing levels of maize/soybean with rice husk (Table $1)$.

Table 1 Composition of the experimental diets, for finishing broiler chickens

\begin{tabular}{|c|c|c|c|c|}
\hline \multirow{3}{*}{ Ingredients(\%) } & \multirow{2}{*}{\multicolumn{2}{|c|}{ Rations }} & & \\
\hline & & & & \\
\hline & DI & $\mathrm{D} 2$ & 1) 3 & \\
\hline Maize & 40.00 & 40.00 & 34.00 & \\
\hline SB-Full fat & 36.00 & 32.70 & 27.80 & \\
\hline Rice husk & 12.33 & 22.51 & 34.39 & \\
\hline Palm oil & 4.00 & 1.00 & - & \\
\hline Bone meal & 2.50 & 2.50 & 2.50 & \\
\hline Oyster shell & 0.50 & 0.50 & 0.50 & \\
\hline${ }^{*}$ Premix (Vit/Min) & 0.25 & 0.25 & 0.25 & \\
\hline Salt ( $\mathrm{NaCl})$ & 0.25 & 0.25 & 0.25 & \\
\hline Methinione & 0.17 & 0.19 & 0.21 & \\
\hline Lysine & - & 0.10 & 0.10 & \\
\hline Total & 100 & 100 & 100 & \\
\hline Determined Analysis & D1 & D2 & D3 & NRC(1994) \\
\hline Crude protein $\%$ & 19.90 & 18.10 & 15.90 & $18-20$ \\
\hline Fat $\%$ & 1100 & 8.08 & 7.40 & \\
\hline Ash \% & $|4.3|$ & 17.40 & 13.40 & \\
\hline Fibre $\%$ & 4.78 & 5.3 & 5.60 & \\
\hline \multicolumn{5}{|l|}{ Calculated Analysis } \\
\hline 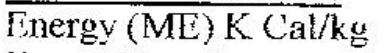 & 3203.76 & 2884.15 & 2566.42 & 3200 \\
\hline Energy/Protein matio & 160.20 & 160.20 & 16.40 & 160 \\
\hline Methionine $\%$ & 0.45 & 0.45 & 0.45 & $0.32-0.38$ \\
\hline Lysine \% & 1.06 & 1.08 & 1.02 & $0.85-1.00$ \\
\hline Calcium \% & 1.33 & 1.33 & 1.33 & $0.80-0.90$ \\
\hline Phosphorus $\%$ & 0.69 & 0.69 & 0.60 & $0.30-0.35$ \\
\hline Cost/kg (\#) & 2369 & 19.56 & 18.18 & \\
\hline
\end{tabular}

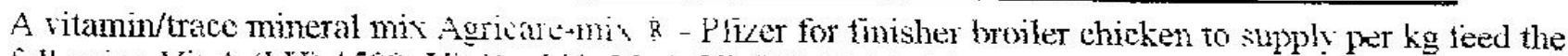

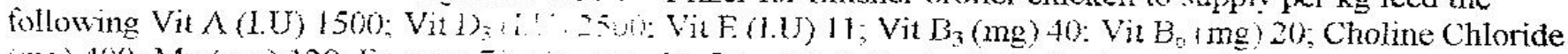

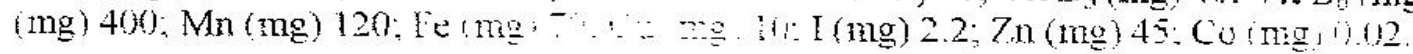




\section{Broiler chickens fed three energy/protein combinations at fixed E:P ratio}

\section{Diet and management}

The ration contained $3203.76 \mathrm{ME}$ vs 19.90 $\% \mathrm{CP}, 2884.15 \mathrm{MF}$ ys $18,10 \% \mathrm{CP}$ and 2566.42 ME vs $15.90 \%$ CP respectively (Table 1). The experimental birds were reared in a standard rearing houses that were adequately ventilated. The decp litter housc used provided ntiformly sized pens of $3.0 \mathrm{~m} \times 3.0 \mathrm{~m}\left(1.21 \mathrm{~m}^{2}\right.$ per bird) The pens were equipped with standard feeding troughs and drinkers. Fecd and water provided ad tibitum. All recommended health practices were strictly observed. Weekly feed intake and body weight were measured. Other parameters were calculated from the feed intake and body weights.

\section{Metabolic trial}

Metabolic trial was carricd ont at $8^{t_{1}}$ week of expcrimentation in specially designed metabolic cages cquipped with separate feeders and watering troughs. For the metabolic trial, two birds were randomly sclectcd from each of the six replicates and housed together in a compartment. The sclected birds were fasted for a day and 3-day acclimatization period was allowed prior to four days faccal collection, $1 \%$ boric acid solution was sprayed on the dropping regularly to prevent escape of nitrogen. Total droppings voided from each replicate group were weighed and recorded. Wet faccal samples were oven dricd at $65^{\circ} \mathrm{C}$ and dry matter content determined. Dried droppings from the same replicates werc then thoroughly pooled and ground and analysed for cnide fibre ether extract and total nitrogen content. The analysis of faccal hitrogen for nitrogen retention and nitrogen digestibility determination was based on the extraction of uric acid from poultry cxcrcta using uranyl acetale, thoreby correcting for NPN in the droppings (Oduguwa and Ogunmodede, 1995). The protein analysis of the feed and the analysis of the feed and the analysis of droppings for nitrogen were by the nethods of A.O.A.C (1990). The nitrogen $\left(\mathrm{N}_{2}\right)$ retention was calculated by the formula:

$\%$ Nitrogen retention $=$

$$
\frac{N_{2} \text { in feed }}{N_{2}}-\frac{N}{\text { in foed }} \text { in excreta X } 100
$$

Also, apparent $\mathrm{N}_{2}$ digestibility was calculated as:

Apparent $\mathrm{N}$ digestibility $=$

$\mathrm{N}_{2}$ intakc(gDM) - $\mathrm{N}_{2}$ output (gDM) $\mathrm{X} 100$ ither uric acid extraction $\mathrm{N}_{2}$ intake (gDM)

While Dry matter digestibility = Fecd inlake (gDM) - Faecal output (gI)M) x 100

\section{Blood metabolites} Feed intake (gDM)

Blood samples were collected separately from 3 birds per replicate group in specimen bottles with and without EDTA for plasma and serum analysis respectively Packed cell volume (PCV), Haemoglobin concentration $(\mathrm{Hb})$ and red blood coll (RBC) were determincd using Wintrobes microhaematocrit. colorimetry cyanomethacmoglobin method and improved Neubauer haemocytometer. respectively. Mcan corpuscular volume (MCV. Mean corpiscular hacmoglobin (MCH) and Mean corpuscular hacmoglobin concentration (MCHC) were computed according to Jain (1986). Serum protein. albumin, globulin were analyzed colorimetrically using diagnostic reagent kit (Reanal Diagnosztikai Reagents, Kešlet, Hungary). The creatinine was determined using Jaffe reaction described by Ojo (1995).

\section{Data collection and analysis}

Weekly records were taken on body weight and feed intake. Daily record of mortality and health problems were recorded and mortality was expresscd as the percentage at the end of experiment. Daily quantity of wet droppings voided and feed intake were taken during the metabolic trials and expressed in terms of dry matter (DM). Percent digestibilities were calculated. The data gencrated from the study were subjected to analysis of variance and significan means separated using Duncan's Multiple Range Test as outlined by Steel and Torrie (1980) a1 the 0.05 level of probability

\section{Results and Discussion}

The analysis of the dicts (Table 1 ) was done on dry matter (DM) basis, the energy/protcin ratio. methionine. lysine calcium and phoshorus concentrations were similar across all dictary 
treatments. There was variation in protein, energy and fat content. Despite the variations in the levels of maize, full-fat soyabean, rice offal and palm oil in the experimental diets, there was an excellent uniformity in the $E: P$ ratio. As mentioned in the introduction, the widening or decline of E:P ratio that was extensively reported by Boorman and Wilson (1977); Scott et al., (1982) and Pond et al.,(1995) were completely eliminated to arrive at fixed E:P ratio of 160:1 recommended by NRC (1994). The control dict (D1) was formulated to meet the minimum requirement of finishing broilcr chicken (NRC, 1994).

Linear growth response was observed in terms of performance (Table 2). This suggested that any further reduction in energy - protein density. at E:P ratio of $160: 1$ would result in poorer performance. However, birds fed diet D1 containing $19 \% \mathrm{CP}$ and $3203.76 \mathrm{ME}$ had the highest $(\mathrm{P}<0.05)$ final weight. This was a direct effect of the corresponding high intake of protein and energy which were properly utilized for growth. The weight gain for the control group (D1) was numerically higher $(\mathrm{P}>0.05)$ than that of other dietary combinations and the difference was not significant $(P>0.05)$. this was because of feed intake that increased linearly to overcome energy-protein deficiency and the cfficiency of feed comversion decreased proportionally. The CP:Gain and ME:Gain ratios (Table 2) buttressed $(\mathrm{P}<0.05)$ the earlier observation noted in the feed conversion efficiency.

Table 2 Performance of experimental birds at the finisher phase

\begin{tabular}{lllll}
\hline Measurements & D1 & D2 & D3 & SEM \\
\hline Initial live weight (g) & $\mathbf{4 6 7 . 3 0}$ & $\mathbf{4 6 7 . 3 0}$ & 457.29 & 21.10 \\
Final live weight (g) & $1535.17^{\mathrm{a}}$ & $1336.80^{\text {ab }}$ & $1261.99^{\mathrm{b}}$ & 62.73 \\
Weight gain (g) & 1067.87 & 869.50 & 804.70 & 67.26 \\
Feed intake (g) & 2880.62 & 3072.02 & 3175.90 & 188.37 \\
$\quad$ Energy intake (ME) Kcal/kg & 9226.26 & 8860.11 & 8148.38 & 211.00 \\
$\quad$ Protein intake (g) & $573.24^{\mathrm{a}}$ & $556.04^{\mathrm{a}}$ & $504.96^{\mathrm{c}}$ & 3.22 \\
Feed conversion ratio & 2.69 & 3.53 & 3.95 & 0.46 \\
$\quad$ ME: Gain ratio & $\mathbf{8 . 6 4 ^ { \mathrm { a } }}$ & $10.19^{\mathrm{b}}$ & $10.13^{\mathrm{c}}$ & 0.19 \\
CP: Gain ratio & $\mathbf{0 . 5 4 ^ { \mathrm { a } }}$ & $0.64^{\mathrm{b}}$ & $0.63^{\mathrm{c}}$ & 0.05 \\
PER & 1.86 & 1.56 & 1.56 & 0.00 \\
Mortality \% & 2.38 & 2.38 & 2.38 & 0.00 \\
\hline \hline
\end{tabular}

Mean on the same row having the same superseript or no superseript are not significantly different $(\mathrm{P}>0.05)$

Table 3 Feed cost analysis

\begin{tabular}{llll}
\hline & D1 & D2 & D3 \\
\hline Cost of feed/kg (A*) & 23.16 & 19.56 & 18.18 \\
Total cost of feed/bird (A) & 68.24 & 60.09 & 57.74 \\
Feed cost/kg wt. Gain (A) & 63.73 & 69.04 & 57.74 \\
¿farginal cost/kg wt. Gain (At) & 0.00 & 6.31 & 8.08 \\
\hline
\end{tabular}

- All costing were done in Naria

Efficiency of the diet was reduced even though

- the $E: P$ ratio was kept fixed and the efficiency is:lined progressively with the increase in feed -+ ake. The feed intake was statistically $(\mathrm{P}>0.05)$

- same across the treatments. Birds on Faments D2 and D3 consumed more feed to :-apensate for the dictary inadequacy, as birds are known (Scott, et al., 1982) to consuste hore feed to meet their mutritional necds. The ovcrall best performance response observed in the control group (D1) could be attributed to the relatively good proximate composition of the diet (D1), low dietary fibre content as well as better digestibility (Table 4 ). 


\section{Broileff chickens fed three energy/protein combinations at fixed E:P ratio}

Table 4 Results of Metabolic trials at Finisher Phase of broiler chicken

\begin{tabular}{lllll}
\hline Parameters & $\mathrm{D} 1$ & $\mathrm{D}$ & $\mathrm{D}$ & $\mathrm{SEM}$ \\
\hline Dry Matter digestibility & $77.22^{\mathrm{a}}$ & $71.53^{\mathrm{b}}$ & $68.71^{\mathrm{c}}$ & 0.14 \\
Crude fibre digestibility $(\%)$ & $30.04^{\mathrm{a}}$ & $23.64^{\mathrm{b}}$ & $21.94^{\mathrm{b}}$ & 0.20 \\
Ether extract digestibility $(\%)$ & $88.17^{\mathrm{a}}$ & $79.11^{\mathrm{b}}$ & $73.02^{\mathrm{c}}$ & 0.20 \\
Nitrogen retention $(\%)$ & $54.87^{\mathrm{c}}$ & $64.32^{\mathrm{b}}$ & $73.02^{\circ}$ & 0.28 \\
Apparent nitrogen digestibility (\%)87.55 & 86.85 & 87.40 & 0.23 \\
\hline \hline
\end{tabular}

Means on the same row having the same superscript are not significantly different.

The lower body weight noticed in the treatments D2 and D3 (as showed in Table 2) was in agreement with the observations of Chi (1985) who noticed delayed attainment of target wcight in chickens when dietary mutrients intake was low, particularly the energy and protein density of the diet. The digestibility percentages showed a decreasing trend across the treatments while the nitrogen retention increased across the treatment. This is explainable by the bulkiness and the degree of dilution of dicts with fibre sources - rice husk (Table 1). The implications of dilution of diet with a fibre-rich feedstuff have been well documented by Longe and Ogedegbe, (1989). These workers observed a proportionate decline in the percentage digestibility when chicken diets were diluted with fibrous feedstuff. The dietary inclusion (Table 1) of high amoumt of rice husk (22.51 $34.39 \%$ ) increased the fibre content of the resulting rations (D2 and D3) which resulted in progressive decline in the digestibility percentages (Table 4) and the overall mutrient utilization. This observation corroborate the fact that Non-starch polysaccharide (NSP) depressed metabolizable energy (ME) and crude protein (CP) utilization hence the lower weight gain, poar feed conversion ratio noticed in treatments D2 and D3.

Values for the haematological parameters particularly the $\mathrm{PCV}, \mathrm{Hb}, \mathrm{RBC}$ and $\mathrm{MCHV}$ (Table 5) were significantly $(\mathrm{P}<0.05)$ higher in birds fed control diet (3203.76 ME vs $19.9 \%$ CP) than in birds fed diets with lower energy protein density ( $\mathrm{D} 2$ and $\mathrm{D} 3$ ) and the values decreascd with dccreased levels of dietary levels of energy and protein. Total blood protein, albumin and globulin values (Table 5) also showed linear relationships. The values decreased with decrease in the level of $\mathrm{ME}$ and $C P$ in the dict inspite of the fact that $E: P$ ratio were the same. Total blood protein was reported (Allison, 1955) as an indication of reduction in total protein in an animal. The gradual reduction $(P<0.05)$ in total blood protein (Table 5) indicated a decline in the efficiency of protein utilization. 
Idowu, Eruvbetine, Oduguwa, Bamghose and Abiola

Table 5 Haematology and serum chemistry of experimental broiler chickens (8 weeks old)

\begin{tabular}{|c|c|c|c|c|c|}
\hline Parameters & D) & $\mathrm{D} 2$ & $\begin{array}{l}\text { Rations } \\
\mathrm{D} 3\end{array}$ & - & SEM \\
\hline $\operatorname{PCV}(\%)$ & $33.20^{\mathrm{a}}$ & $31.10^{\mathrm{b}}$ & $29.57^{\circ}$ & & 0.04 \\
\hline $\mathrm{Hb}(\mathrm{g} / \mathrm{dl})$ & $11.06^{\mathrm{a}}$ & $10.27^{\mathrm{b}}$ & $9.71^{\mathrm{c}}$ & & 0.05 \\
\hline $\mathrm{RBC}\left(10^{5} / \mathrm{mmm}^{3}\right)$ & $3.70^{\mathrm{a}}$ & $3.47^{b}$ & $9.71^{\mathrm{e}}$ & & 0.04 \\
\hline $\mathrm{MCHC}(\mathrm{FI})$ & $90.00^{\mathrm{a}}$ & $89.01^{b}$ & $88.50^{c}$ & & 0.05 \\
\hline $\mathrm{MCH}$ (f/mg) & 30.00 & 29.63 & 29.60 & & 0.02 \\
\hline $\mathrm{MCHC}$ & 34.00 & 33.00 & 32.57 & & 0.03 \\
\hline Total protein $(\mathrm{mg} / \mathrm{d} l)$ & $85.19^{\mathrm{a}}$ & $80.83^{\mathrm{b}}$ & $77.64^{c}$ & & 0.38 \\
\hline Albumin $(\mathrm{mg} / \mathrm{dl})$ & 57.30 & 48.83 & 46.80 & & 0.42 \\
\hline Globulin (mg/dl) & 33.89 & 32.00 & 30.48 & & 0.73 \\
\hline Albumin/globulin ratio & 1.51 & 1.53 & .1 .52 & $\vdots$ & 0.03 \\
\hline Uric acid (mg/dI) & $41.08^{\mathrm{a}}$ & $38.42^{b}$ & $37.50^{\circ}$ & & 0.15 \\
\hline Creathnine (mg/dl) & $1.94^{\mathrm{a}}$ & $1.88^{b}$ & $1.73^{\circ}$ & & 0.01 \\
\hline
\end{tabular}

Means within the same row with the same superscript or no superscript are not significantly different $(\mathrm{P}>0.05)$ $\mathrm{PCV}=\mathrm{Packed}$ cell volume; $\mathrm{Hb}=$ Haemoglobin $\mathrm{RBC}=\mathrm{Red}$ blood cell; $\mathrm{MVC}=\mathrm{Means}$ corpuscular volume; $\mathrm{MCH}=\mathrm{Mean}$ corpuscular haemoglobin; $\mathrm{MCHC}=$ Mean corpuscular haemoglobin concentration .

This also provided a possible explanation for the observed steady decline in weight gain across the dietary treatment (Table 2). Babatunde and Pond (1981) noted that blood uric acid concentration was inversely related to efficiency of protein utilization. In this study, the blood uric acid decreased with decreased level of dietary protein levels. This suggested that there could be another source of creatinine and uric acid in the blood since the control (D) group birds that had the highest senum creatinine and wric acid also have the heaviest body weight Table 2). This perhaps may be due to the break jown of phosphocreatine.

Treatment D3 was the poorest in the economy of production by gaining $1 \mathrm{~kg}$ body weight wilh

I.81 which was not significantly different z-0.05) across the experimental treatments. - $\mathrm{x}$ cost benefit pattern (cost of feed $/ \mathrm{kg}$ weight $\sum n^{2}$, followed an increasing trend with jecreasing energy and protein content of the -15. The successful reduction in the cost of - per kilogram was not translated into least a of production per $\mathrm{kg}$ gain and so the -zt 2 ly cheaper diets D2 and D3 did not bring ir i- afficient feed conversion that could result $=$ least cost of production. This result agreed - I jings of Ekenyem (2002) who reported Inir reducing feed cost/kg was onty justifiable when production results is comparable with the standard (control). The overall response assessment showed that when both energy and protein density of broiler diets are reduced at fixed E:P ratio the feed intake would increase while the feed utilization efficicncy dccreases.

\section{Reference}

Allison, J.B.Z. 195). Biological evaluation of proteins. Physiological Rev. 35:664 -669 .

A.0.A.C. 1990. Association of Official Analytical Chemists. Official method of analysis. $15^{\text {th }}$ ed. Washinton, D.C

A.R.C. 1975. The Nutrient Requirment of Farm Livestock. No 1, Poultry, $2^{\text {nd }} \mathrm{Ed}$. Agricultural " Research Council, London.

Babatunde, G.M and Fetuga,B.L. 1976. Determination of minimum crude protein requirements for broiler starter and finishers in the tropics. Nig. J. Animal Prod. 3:126-138. 
Babatunde, G.M and Pond, W.G. 1987. Nutritive value of Nigerian rubber seed (Hevea brasiliensis), L - Rubber seed meal. Nutr. Rep. Int., 36: 617-630.

Bow A. A. 1987. Artimal Nutrition. $1^{\text {st }}$ ed. ohe Wiley and Sons, New York.

Bay, K.N. and Wilson, B.J. 1977. wh and poultry meat production. atry Sci. Symposium, No 12. burgh: Bristish Poult. Soi. Ltd.

M.S. 1995, Effect of low protein diets growing leghorn pullets upon absequent laying performance. Brit. Boult. Sci. 26: $433-446$.

Ekenyem, B.U. 2002. Economic viability of raising weaner rabbits on Guinea grass (Panicum maximum) supplemented with graded levels of poultry" grower ration Prpoceedings of $27^{\text {th }}$ Ann Conf. Nig. Society for Animal productyion. $17-21^{\text {st }}$ March, 2002, Akure. Pp 180 - 181.

Fetuga, B.L. 1984, Techniques in feed formulation. Paper presented at the Feedmill ' Management Training Workshop, Dept. of Agric. Econs., Univ. of Ibadan, Nigeria.

Jain, N.C. 1986. Schalm Vcterinary Haematology $4^{\text {th }} \mathrm{ed}$. Lea and Febiger, Philadelphia, U.S.A.
Longe, O.G. and Ogedegbe, N.E.E. 1989. Influence of fibre on metabolizable energy of diet and performance of growing pullets in the tropics. Bristish Poult. Sci. 30: $193-105$.

N.R.C. 1994. National Research Council Nutrient Requirements of Poultry, $9^{\text {th }}$ Rev cd. National Academy press, Washington, D.C.

Oduguwa, O.O and Ogummodede, B.K. Growth and protein utilization by broiler chicks fed three commercial micronutrient mixtures. Int. J. Anim. Sci. 10: $171-175$.

Olomu, J.M. 1980. Protein and Energy Nutrtition of Poultry in Nigeria. In Brteeds and Nutrition of Poultry in Nigeria. Pub. By Nig. Branch World's Poultry Sci. Assoc. pp $41-58$.

Ulomu, J.M and Offiong, S.A. 1980. The effects of different protein and energy and time of change from starter to finisher ration on the performance of broiler chicken in the tropics. Poult. Sci. 59: $828 \div 835$.

Ojo, D.A, 1995. Personal communication. Mcdical diagnostic laboratory, University of Agric. Abeokuta, Nigeria.

Steel, R.G.D and Torrie, J.H. 1980. Principles and procedure of statistics. McGraw-Hill bode Company, New York.

(Received 18July 2001; Accepted 22 May 2002) 